\title{
Effects of TAG/DNA ratio and age of cyprids on post-metamorphic growth and survival in the barnacle Balanus amphitrite
}

\author{
Vengatesen Thiyagarajan, Tilmann Harder and Pei-Yuan Qian* \\ Department of Biology, The Hong Kong University of Science and Technology (HKUST), Clear Water Bay, Kowloon, \\ SAR Hong Kong, China. *Corresponding author: e-mail: boqianpy@ust.hk
}

\begin{abstract}
The nauplii of Balanus amphitrite (Cirripedia: Thoracica) were cultured on a daily diet of Chaetoceros gracilis at different concentrations. Both young (zero-day old) and aged (six-day old) cyprids were subject to attachment assays, followed by studies of juvenile growth and survival for two weeks under laboratory conditions. The TAG/DNA ratio of cyprid increased in the following order of food concentrations: $10^{6}>10^{5}>10^{4}$ cells $\mathrm{ml}^{-1}$. More than $70 \%$ of cyprids metamorphosed in the presence of conspecific settlement factor, irrespective of their TAG/DNA ratio. The juvenile growth and survival in young cyprids surpassed that of the aged cyprids. The TAG/DNA ratio had no significant effect on juvenile growth and survival in both young and aged cyprids. The negative effect of delayed metamorphosis on juvenile growth and survival appeared to be independent of the TAG/DNA ratio.
\end{abstract}

\section{INTRODUCTION}

The attachment and metamorphosis of cyprids is the most critical period in the life history of barnacles, during which dramatic changes in morphology, physiology and habitat occur. Whilst cyprids delay metamorphosis in the absence of suitable substrata (Lucas et al., 1979), in the presence of pheromonal cues, such as conspecific settlement factor, a large proportion of cyprids readily metamorphose into juveniles (Rittschof et al., 1984). In addition to predation, competition and physical stress the fate of juveniles after metamorphosis is determined by the larval physiological condition. In particular, juvenile survival, growth rates or rates of development are compromised in some species if individuals experience food limitation during larval development or if they have delayed their metamorphosis (Pechenik et al., 1993; Qian \& Pechenik, 1998; and references therein).

In Semibalanus balanoides, the vertical distribution of juveniles as well as the temporal variation in juvenile growth potential and survival has been correlated with the variation in the physiological condition of cyprids (Jarrett \& Pechenik, 1997; Miron et al., 1999). In Balanus amphitrite, delayed metamorphosis resulted in reduced juvenile growth and survival (Pechenik et al., 1993). During naupliar development, dietary triacylglycerols (TAG) are accumulated and stored as energy reserves in specialized oil cells (Walker et al., 1987). Non-feeding cyprids can delay their metamorphosis whilst utilizing stored lipid reserves (Lucas et al., 1979). The physiological condition of cyprids, thus, is not only determined by the larval age (Lucas et al., 1979; Miron et al., 2000) but also by the quantity (West \& Costlow, 1988) and quality (Harder et al., 2001) of the naupliar diet. Up to four days, juveniles utilize these energy reserves until their digestive system is completely developed (Rainbow \& Walker, 1977).
Given that cyprid metamorphic success, juvenile growth and survival are at least in part due to the organic content of cyprids (Jarrett \& Pechenik, 1997), the quantity of algal food provided to naupliar larvae might affect the postmetamorphic growth. More specifically, energy reserve and age of cyprids may either act independently on juvenile growth, or they may have a combined effect with energy reserve playing a major role. In this study, these hypotheses were tested under controlled laboratory conditions. The nauplii of $B$. amphitrite were mass cultured on a daily diet of Chaetoceros gracilis at three concentrations. Both newly transformed and aged cyprids were subject to attachment assays, followed by studies of juvenile growth and survival.

\section{MATERIALS AND METHODS \\ Cultures of algae and larvae}

Between August and February 2001/2002, adult Balanus amphitrite were collected from piling in the intertidal zone of Port Shelter, Hong Kong. After 24 h of exposure to air, they were returned into seawater to induce the release of larvae. Larvae were reared to cyprid stage at a density of two larvae $\mathrm{ml}^{-1}$ in filtered $(0.22 \mu \mathrm{m})$ seawater $(30 \mathrm{psu})$ (FSW) at $28^{\circ} \mathrm{C}$. The nauplii obtained from single mass spawning were divided into three batches of 4000 larvae each and reared on a daily diet of Chaetoceros gracilis at three concentrations: $10^{4}, 10^{5}$, and $10^{6}$ cells ml ${ }^{-1}$ (hereafter referred to as 'food concentration'). The diatom was semi-continuously grown in $\mathrm{f} / 2$ medium in batch culture at $28^{\circ} \mathrm{C}$ under

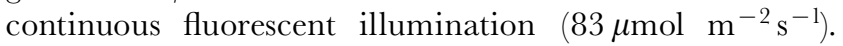
Aliquots of newly transformed cyprids (young cyprids) were immediately utilized in attachment assays and remaining cyprids were aged in darkness at $8^{\circ} \mathrm{C}$ for six days prior to utilization (aged cyprids). 
Table 1. Results of a three-way randomized block ANOVA examining the effect of food concentration $\left(10^{4}, 10^{5}\right.$ and $10^{6} \mathrm{cells} \mathrm{ml}^{-1}$ : fixed factor), cyprid age (0 and 6-day: fixed factor) and blocks (larval batch 1 to 3: random factor), on the TAG/DNA ratio of cyprids, per cent metamorphosis and juvenile basal diameter of Balanus amphitrite. Due to lack of replication within blocks, second-order interaction was not tested. Both the TAG/DNA ratio and the juvenile basal diameter data were log-transformed.

\begin{tabular}{|c|c|c|c|c|c|c|c|c|c|c|}
\hline \multirow[b]{2}{*}{ Source of variation } & \multirow[b]{2}{*}{$\mathrm{df}$} & \multicolumn{3}{|c|}{ TAG/DNA ratio } & \multicolumn{3}{|c|}{$\%$ metamorphosis } & \multicolumn{3}{|c|}{ Juvenile basal diameter } \\
\hline & & MS & $F$ & $P$ & MS & $F$ & $P$ & MS & $F$ & $P$ \\
\hline Food concentration $(\mathrm{A})$ & 2 & 0.2686 & 167.08 & $<0.01$ & 16.40 & 0.46 & 0.66 & 0.0337 & 339.95 & $<0.01$ \\
\hline Cyprid age $(\mathrm{B})$ & 1 & 0.0307 & 197.85 & $<0.01$ & 336.78 & 183.79 & $<0.01$ & 0.0001 & 1.78 & 0.31 \\
\hline Block (C) & 2 & 0.0029 & 1.78 & 0.27 & 133.15 & 3.98 & 0.12 & 0.0001 & 0.28 & 0.76 \\
\hline $\mathrm{A} \times \mathrm{B}$ & 2 & 0.0001 & 1.30 & 0.36 & 0.52 & 0.12 & 0.88 & 0.0001 & 2.19 & 0.22 \\
\hline $\mathrm{A} \times \mathrm{C}$ & 4 & 0.0016 & 17.22 & $<0.01$ & 35.74 & 8.56 & $<0.03$ & 0.0001 & 5.26 & 0.06 \\
\hline $\mathrm{B} \times \mathrm{C}$ & 2 & 0.0001 & 1.71 & 0.28 & 1.83 & 0.43 & 0.67 & 0.0001 & 4.50 & 0.09 \\
\hline Error & 4 & 0.0001 & & & 4.17 & & & 0.0001 & & \\
\hline
\end{tabular}

\section{Measurement of TAG and DNA of cyprids}

Fifty cyprids of each age group originating from different food concentrations were homogenized in $2.5 \mathrm{ml}$ of deionized water by ultrasonication. Lipids were extracted with one $\mathrm{ml}$ of $2: 1(\mathrm{v} / \mathrm{v})$ chloroform:methanol. The TAG content was measured spectrophotometrically as free glycerol after saponification and derivatization with chromotropic acid and tripalmitin as standard (Barnes

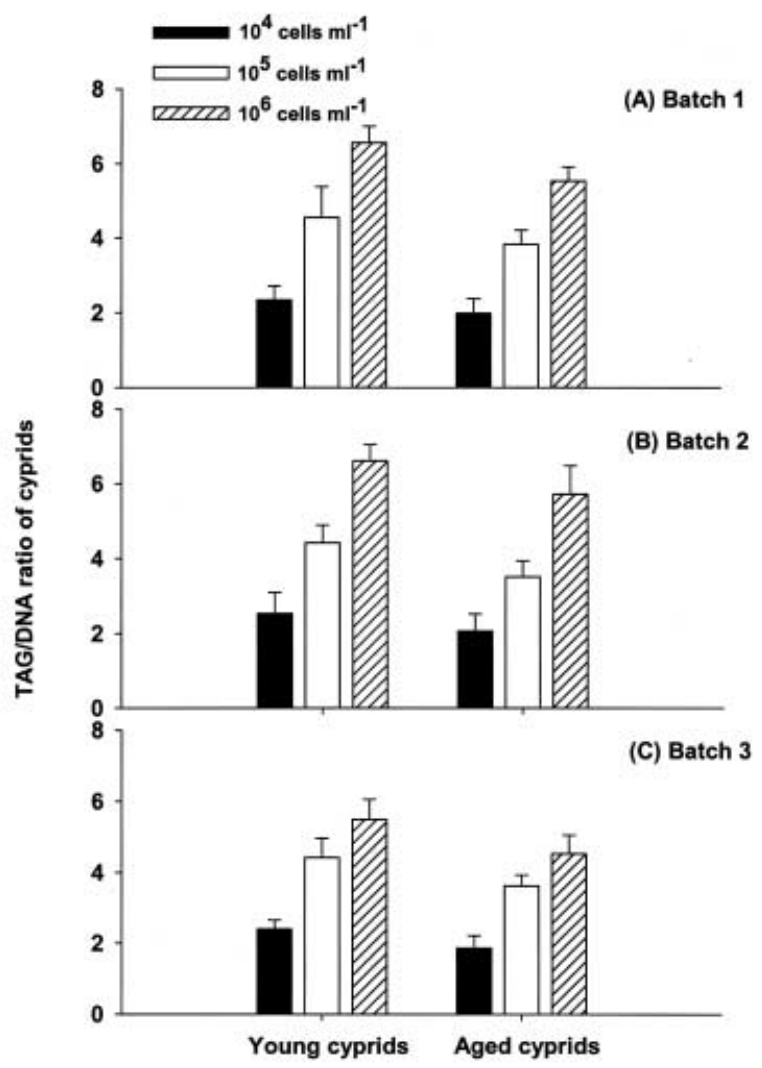

Figure 1. Balanus amphitrite. Effect of food (Chaetoceros gracilis) concentration and cyprid age on the TAG/DNA ratio of cyprids. Each data point represents the mean $( \pm \mathrm{SD})$ of six measurements of different samples. Data are presented for three larval batches (A to $\mathrm{C}$ ).
\& Blackstock, 1973). Nucleic acids were extracted from aliquots of ten cyprids according to Clemmesen (1993). The DNA was stained with PicoGreen ${ }^{\circledR}$ (Molecular Probes, USA) and quantified by spectroflourometry $\left(\lambda_{\mathrm{ex}}=\right.$ $480 \mathrm{~nm}, \lambda_{\mathrm{em}}=520 \mathrm{~nm}$ ) with herring sperm DNA as standard. Six aliquot samples were used for each measurement.

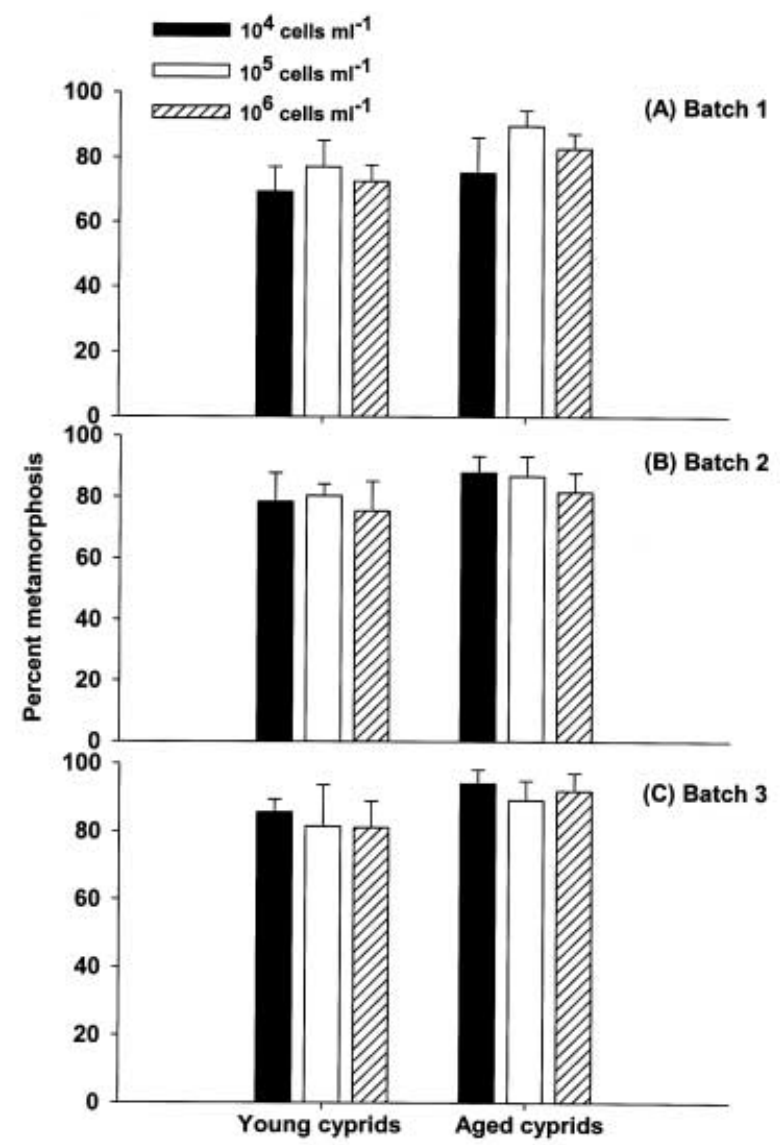

Figure 2. Balanus amphitrite. Effect of food (Chaetoceros gracilis) concentration and cyprid age on metamorphosis in the presence of conspecific settlement factor. Each data point represents the mean $( \pm \mathrm{SD})$ of six dishes with 15-20 cyprids in each dish. Data are presented for three larval batches (A to $\mathrm{C}$ ). 


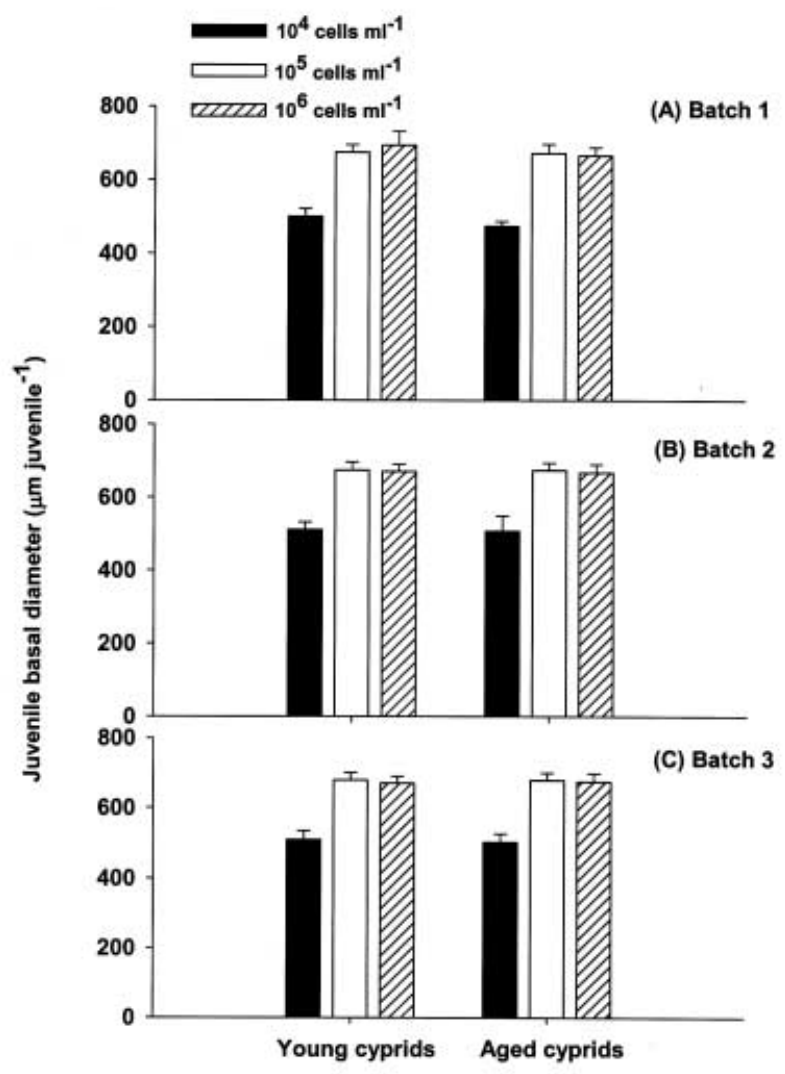

Figure 3. Balanus amphitrite. Effect of food (Chaetoceros gracilis) concentration and cyprid age on the juvenile basal diameter. Each data point represents the mean $( \pm \mathrm{SD})$ of six dishes with 6-10 individuals in each dish. Data are presented for three larval batches (A to $\mathrm{C}$ ).

\section{Metamorphosis of cyprids}

Cyprids of each age group originating from different food concentrations were induced to metamorphose by conspecific settlement factor (SF). Settlement factor was isolated according to Rittschof et al. (1984). Five ml of SFsolution (equivalent to five $\mu \mathrm{g} \mathrm{ml}^{-1}$ bovine serum albumin; Bradford, 1976) was transferred into polystyrene dishes and incubated for one hour at $28^{\circ} \mathrm{C}$. Subsequently, the solution was discarded and dishes were air-dried. Under the dissection microscope, cyprids were introduced together with four ml of FSW. Dishes were incubated for
$24 \mathrm{~h}$ after which the percentage of metamorphosis was scored. Six replicate dishes (pseudoreplicates) were used for each food concentration and cyprid age.

\section{Juvenile growth and survival}

The procedure for monitoring juvenile growth and survival was adopted from Pechenik et al. (1993). The basal diameter (rostrum to carina) of newly metamorphosed juveniles $(<24 \mathrm{~h}$ old $)$ was determined under the microscope. Dishes with ten juveniles were attached to glass rods (six dishes $\operatorname{rod}^{-1}$ ) and reared at $28^{\circ} \mathrm{C}$ for two weeks with a 3:1 mixture of $C$. gracilis and Isochrysis galbana

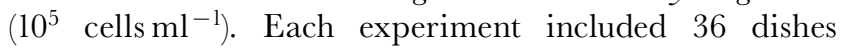
(three food concentrations $\times$ two cyprid ages $\times$ six pseudoreplicates). After measuring basal diameters, adults were carefully removed from the dishes and grouped in preweighed foil pans (six to ten adults $\mathrm{pan}^{-1}$ ) to measure the ash-free dry weight (AFDW). Specimens were dried at $75^{\circ} \mathrm{C}$ for $48 \mathrm{~h}$ and subsequently weighed to the nearest $0.001 \mathrm{mg}$ (Supermicro S 4 electronic ultra-microbalance, Sartorius, Germany). After being ashed for six to eight hours at $525^{\circ} \mathrm{C}$ the pans were reweighed. The AFDW was calculated by dividing the total weight loss by the number of adults pan $^{-1}$. The whole experiment was repeated thrice with larvae obtained from different broodstocks (larval batches 1 to 3 ).

\section{Data analysis}

Data were checked for normality with Shapiro-Wilk test and for homogeneity of variance with Cochran's $C$-test before proceeding with parametric analysis. All mean $(\mathrm{N}=6)$ values within the levels of food concentration and cyprid age were used for statistical analysis. Three-way randomized block analysis of variance (ANOVA) model was used to examine the effects of food concentration (fixed factor), cyprid age (fixed factor) and larval batch (random factor) on TAG/DNA ratio of cyprids, metamorphosis, juvenile and adult basal diameter, final tissue weight and survivorship. Differences in means of fixed factors in one larval batch might not hold for another batch, so the data obtained from three different batches were used in order to randomize unsuspected sources of variation in the effects of the two main factors (Underwood, 1997). In cases where

Table 2. Results of a three-way randomized block ANOVA examining the effect of food concentration $\left(10^{4}, 10^{5}\right.$ and $10^{6} \mathrm{cells} \mathrm{ml}^{-1}$ : fixed factor), cyprid age (0 and 6-day: fixed factor) and blocks (larval batch 1 to 3: random factor), on the adult basal diameter, final tissue weight and per cent survivorship of Balanus amphitrite. Due to lack of replication within blocks, a second-order interaction was not tested. Both the adult basal diameter and final tissue weight data were log-transformed.

\begin{tabular}{|c|c|c|c|c|c|c|c|c|c|c|}
\hline \multirow[b]{2}{*}{ Source of variation } & \multirow[b]{2}{*}{$\mathrm{df}$} & \multicolumn{3}{|c|}{ Adult basal diameter } & \multicolumn{3}{|c|}{ Final tissue weight } & \multicolumn{3}{|c|}{ Survivorship } \\
\hline & & MS & $F$ & $P$ & MS & $F$ & $P$ & MS & $F$ & $P$ \\
\hline Food concentration $(\mathrm{A})$ & 2 & 0.0212 & 2.61 & 0.18 & 0.0001 & 0.26 & 0.77 & 15.38 & 1.28 & 0.37 \\
\hline Cyprid age (B) & 1 & 12.378 & 460.22 & $<0.01$ & 0.0236 & 90.54 & $<0.01$ & 5270.22 & 48.62 & $<0.01$ \\
\hline $\operatorname{Block}(\mathrm{C})$ & 2 & 0.0928 & 3.46 & 0.24 & 0.0002 & 0.74 & 0.57 & 82.72 & 0.98 & 0.56 \\
\hline$A \times B$ & 2 & 0.0642 & 7.61 & 0.05 & 0.0001 & 0.15 & 0.86 & 43.05 & 1.19 & 0.39 \\
\hline $\mathrm{A} \times \mathrm{C}$ & 4 & 0.0268 & 3.19 & 0.14 & 0.0011 & 1.29 & 0.41 & 11.97 & 0.33 & 0.84 \\
\hline $\mathrm{B} \times \mathrm{C}$ & 2 & 0.0081 & 0.96 & 0.51 & 0.0002 & 1.79 & 0.27 & 108.38 & 3.01 & 0.15 \\
\hline Error & 4 & 0.0084 & & & 0.0001 & & & 143.88 & & \\
\hline
\end{tabular}




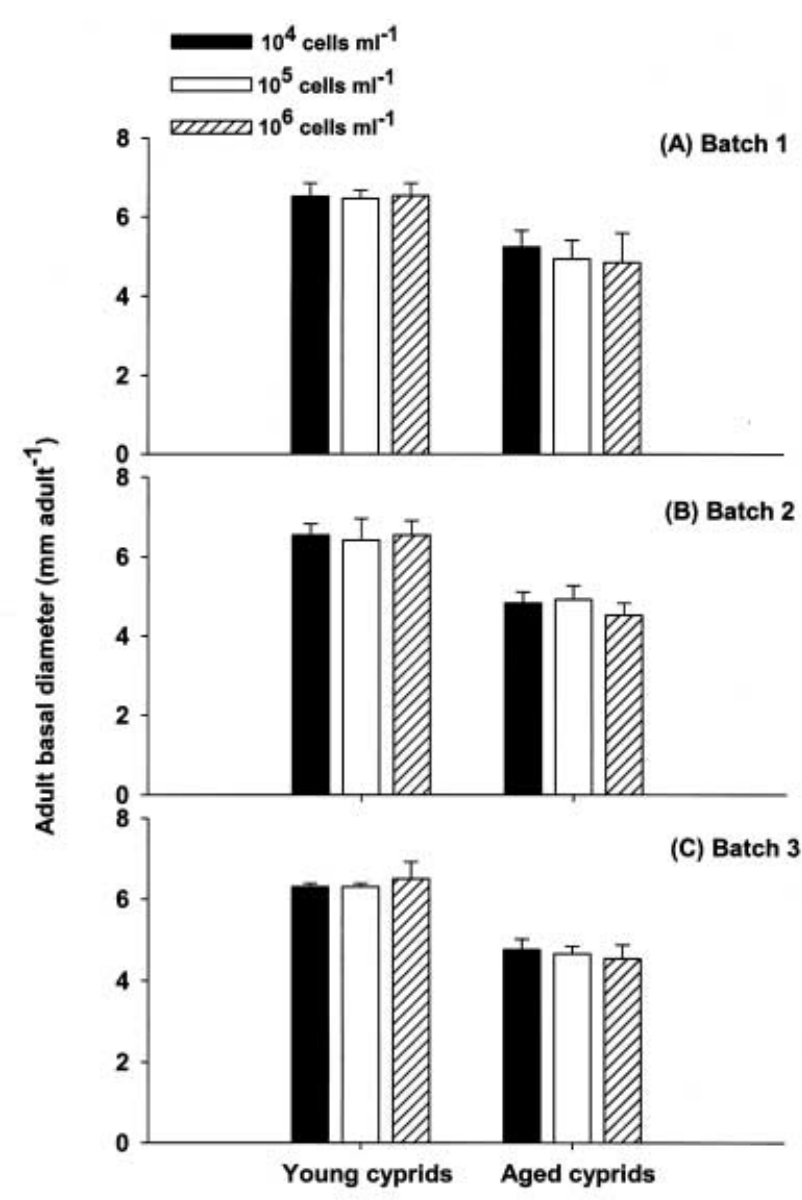

Figure 4. Balanus amphitrite. Effect of food (Chaetoceros gracilis) concentration and cyprid age on the adult basal diameter. Each data point represents the mean $( \pm \mathrm{SD})$ of six dishes with 6-10 individuals in each dish. Data are presented for three larval batches (A to $\mathrm{G}$ ).

factors did not significantly interact, the means of different food concentrations and cyprid age were compared using Tukey multiple comparison test and two-sample $t$-test, respectively. When the interaction between the factors was significant, the effect of each factor was tested at a fixed level of the other factor.

\section{RESULTS}

At all food concentrations, at least $75 \%$ of nauplii metamorphosed into cyprids between day four and day five. Though the TAG/DNA ratio of cyprids was significantly affected both by food concentration and cyprid age (Table 1), there was no significant interaction between the two factors. The TAG/DNA ratio increased in the following order of food concentrations: $10^{6}>10^{5}>10^{4}$ cells $^{-1}$ in all larval batches except batch three, where there was no marked difference between $10^{5}$ and $10^{6}$ cells $\mathrm{ml}^{-1}$, based upon the visual assessment of graphed data (Figure 1). After six days of delay in metamorphosis, the TAG/DNA ratio slightly decreased from the initial level, but it was two to three times higher in cyprids reared at $10^{6}$ cells $\mathrm{ml}^{-1}$ when compared to their counterparts reared at $10^{4}$ cells ml ${ }^{-1}$. Furthermore, the TAG/DNA ratio of aged cyprids reared at $10^{6}$ cells $\mathrm{ml}^{-1}$ was twice as much as that of young cyprids reared at $10^{4}$ cells $\mathrm{ml}^{-1}$.
More than $70 \%$ of young cyprids metamorphosed into juveniles in $24 \mathrm{~h}$ (Figure 2). Whilst the food concentration had no significant effect on metamorphosis, the cyprid age had a significant effect and there was no interaction between food concentration and cyprid age (Table 1). The percentage of metamorphosis of aged cyprids was significantly higher than young cyprids $\left(\mathrm{t}_{16}=3.40, \quad P<0.05\right)$. The overall average juvenile basal diameter had ranged from 473 to $678 \mu \mathrm{m}$ (Figure 3). Food concentration had a statistically significant effect on juvenile basal diameter (Table 1). Whilst the juvenile basal diameter was similar between $10^{5}$ and $10^{6}$ cells ml ${ }^{-1}$, it was significantly lower at $10^{4} \mathrm{cells} \mathrm{ml}^{-1}$ (Tukey test). The interaction term was, however, not significant for food concentration and cyprid age, thus suggesting that the effect of food concentration on juvenile basal diameter is not dependent on cyprid age.

In Table 2, none of the first-order interactions were significant, thus allowing direct conclusions of the main effects. The adult basal diameter, final tissue weight and survivorship were unaffected by food concentration, whereas, cyprid age strongly affected these response variables (Table 2). More than 75\% of juveniles obtained from young cyprids developed into adults with basal diameter and tissue weight ranging from 6.3 to $6.5 \mathrm{~mm}$ and 0.19 to $0.21 \mathrm{mg}$, respectively (Figures $4 \& 5$ ). In contrast, only 35 to $48 \%$ of juveniles obtained from aged cyprids survived

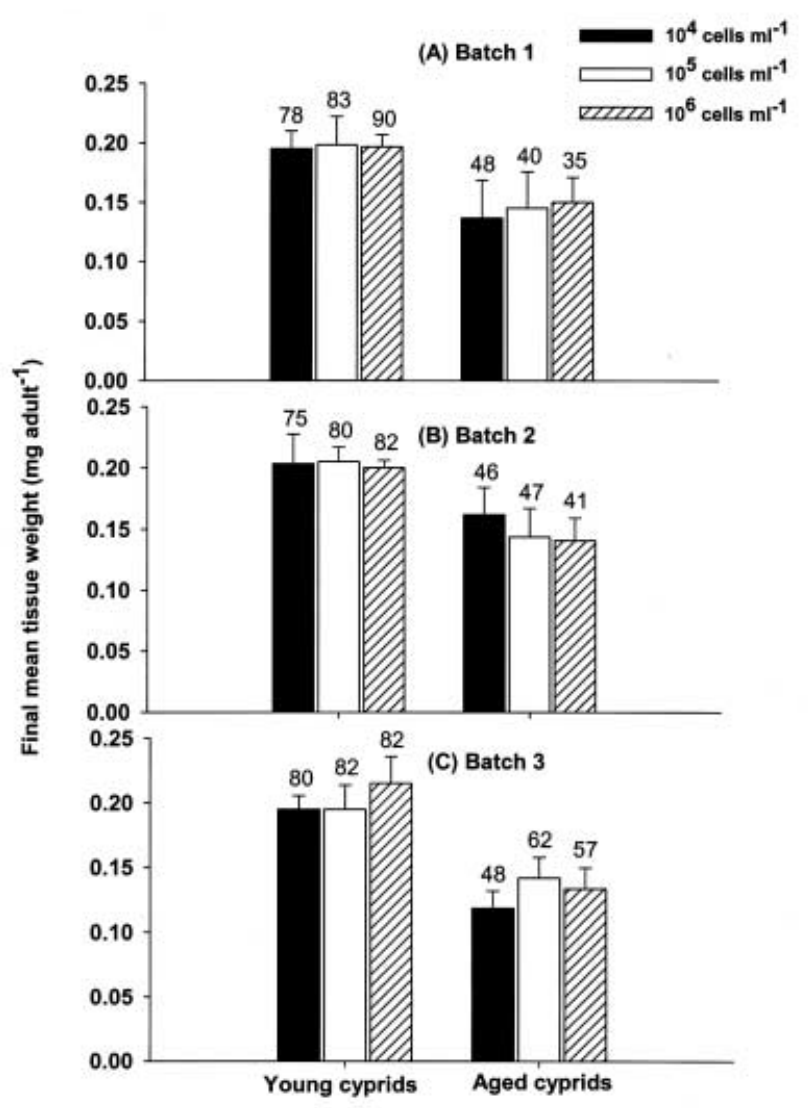

Figure 5. Balanus amphitrite. Effect of food (Chaetoceros gracilis) concentration and cyprid age on the final mean tissue weight of adults. Each data point represents the mean $( \pm \mathrm{SD})$ of six dishes with 6-10 individuals in each dish. The mean percentage of survival of juveniles at the end of the experiment are indicated above the bar. Data are presented for three larval batches (A to $\mathrm{C})$. 
and the final tissue weight of adults obtained from these cyprids was significantly lower than that of the counterparts obtained from young cyprids $\left(\mathrm{t}_{16}=12.41, P<0.05\right.$; Figure 5). The basal diameter of adults obtained from aged cyprids ranged from 4.52 to $5.23 \mathrm{~mm}$, which was significantly smaller compared to that of young cyprids $\left(\mathrm{t}_{16}=18.38 ; P<0.05\right)$. Noticeably, in the two-week experimental period the basal diameter of juveniles at $10^{4}$ cells $\mathrm{ml}^{-1}$ treatment increased dramatically and became statistically equivalent to their counterparts at $10^{5}$ and $10^{6}$ cells ml ${ }^{-1}$ treatments (Figures $4 \& 5$ ).

\section{DISCUSSION}

In accordance with previous investigations, different food concentration used in larval cultures clearly affected the amount of energy reserve in cyprids (West \& Costlow, 1988; Hentschel \& Emlet, 2000). At algal food concentrations below $10^{4}$ cells $\mathrm{ml}^{-1}$, nauplii did not metamorphose into cyprids (data not shown). The TAG/DNA ratio obtained from nauplii cultured at $10^{4}$ cells $\mathrm{ml}^{-1}$ was therefore assumed to be the lower threshold energy level of cyprids. Although the algal cell concentrations employed in this study were not comparable with field conditions (see Qiu \& Qian, 1997), the range of cyprid TAG/DNA ratios obtained from different food concentrations were assumed to reflect cyprid energy reserve levels in the field. This study firstly reports on the influence of cyprid energy reserve on juvenile growth and survival of Balanus amphitrite during the first two weeks. The magnitude of the influence distinctly varied with the age of cyprids. The juvenile growth and survival in young cyprids surpassed that of the aged cyprids. The TAG/DNA ratio of cyprids had no significant effect on the juvenile growth and survival of neither young nor aged cyprids.

Earlier field reports unveiled a drastic variation in metamorphic success of cyprids and early juvenile growth and survival (Raimondi, 1990; Gosselin \& Qian, 1996; Jarrett \& Pechenik, 1997). Whilst effects such as density-dependent mortality, desiccation, grazing, and wave action have been ruled out as potential causative factors (Gosselin \& Qian, 1996), the observed variation was related to endogenous characteristics such as the physiological condition of cyprids (Jarrett \& Pechenik, 1997). The physiological condition of the cyprids is largely determined by their energy reserve (i.e. larval feeding history) and physiological age (Lucas et al., 1979; Miron et al., 2000; Harder et al., 2001). Our results clearly distinguished these two factors, concluding that cyprid age has a stronger impact on juvenile growth and survival than that of cyprid energy reserve. The temporal and spatial variations observed in early juvenile growth and mortality of an intertidal barnacle, thus seems to be explained by delayed metamorphosis rather than by the variations in food availability to naupliar larvae.

In a previous study, it was hypothesized that reduced growth and survival of juveniles originating from aged cyprids was due to the depletion of larval energy reserves (Pechenik et al., 1993). However, energetic characteristics of cyprids alone may insufficiently explain the negative effect of delayed metamorphosis on juvenile growth potential and survival, since our results demonstrated the same effect in aged cyprids with high energy reserves.
A possible explanation for the pronounced negative effect of the cyprid age on juvenile growth and survival may be due to impaired development of juvenile feeding structures, a hypothesis that is in accordance with a similar observation in bryozoans (Wendt, 1996). The detrimental effect of cyprid age on basal diameter, tissue weight and survival observed in this study is consistent with previous findings by Pechenik et al. (1993). The negative effect of delayed metamorphosis does not seem to be limited to barnacles as it has also been reported in other sessile marine invertebrates, such as the polychaete Hydroides elegans (Qian \& Pechenik, 1998). In summary, our study indicates that once nauplii have developed into cyprids, further recruitment stages such as attachment and metamorphosis in the presence of pheromone, juvenile growth and survival are not affected by the cyprids energy reserve, provided cyprids find a suitable habitat for attachment within a specified time limit. Furthermore, results suggest that energetic condition of the cyprid alone is insufficient to explain the negative effect of delayed metamorphosis on juvenile growth and survival.

The authors thank Dan Rittschof (Duke University) and J.W. Qiu (HKUST) for their valuable comments on the outcome of this investigation. We would like to thank the anonymous referees for their constructive comments, particularly the suggestions about statistical analyses. This work was supported by RGC grants (HKUST 6133/99M, CA00/01.Sc01) to P.-Y. Qian.

\section{REFERENCES}

Barnes, H. \& Blackstock, J., 1973. Estimation of lipids in marine animals and tissues: detailed investigation of the sulphophosphovanillin method for total lipids. Fournal of Experimental Marine Biology and Ecology, 12, 103-118.

Bradford, M.M., 1976. A rapid and sensitive method for the quantification of microgram quantities of protein utilizing the principle of protein dye binding. Analytical Biochemistry, 72, 248-254.

Clemmesen, C., 1993. Improvements in the fluorimetric determination of the RNA and DNA content of individual marine fish larvae. Marine Ecology Progress Series, 100, 177-183.

Gosselin, L.A. \& Qian, P.Y., 1996. Early post-settlement mortality of an intertidal barnacle: a critical period for survival. Marine Ecology Progress Series, 135, 69-75.

Harder, T., Thiyagarajan, V. \& Qian, P.Y., 2001. Combined effect of cyprid age and lipid content on larval settlement and metamorphosis of Balanus amphitrite Darwin. Biofouling, 17, 257-262.

Hentschel, B.T. \& Emlet, R.B., 2000. Metamorphosis of barnacle nauplii: effects of food variability and a comparison with amphibian models. Ecology, 81, 3495-3508.

Jarrett, J.N. \& Pechenik, J.A., 1997. Temporal variation in cyprid quality and juvenile growth capacity for an intertidal barnacle. Ecology, 78, 1262-1265.

Lucas, M.I., Walker, G., Holland, D.L. \& Crisp, D.J., 1979. An energy budget for the free-swimming and metamorphosing larvae of Balanus balanoides (Crustacea: Cirripedia). Marine Biology, 55, 221-229.

Miron, G., Boudreau, B. \& Bourget, E., 1999. Intertidal barnacle distribution: a case study using multiple working hypothesis. Marine Ecology Progress Series, 189, 205-219.

Miron, G., Walters, L.J., Tremblay, R. \& Bourget, E., 2000. Physiological condition and barnacle larval behavior: a preliminary look at the relationship between TAG/DNA ratio and larval substratum exploration in Balanus amphitrite. Marine Ecology Progress Series, 198, 303-310. 
Pechenik, J.A., Rittschof, D. \& Schmidt, A.R., 1993. Influence of delayed metamorphosis on survival and growth of juvenile barnacles Balanus amphitrite. Marine Biology, 115, 287-294.

Qian, P.Y. \& Pechenik, J.A., 1998. Effects of larval starvation and delayed metamorphosis on juvenile survival and growth of the tube-dwelling polychaete Hydroides elegans (Haswell). Fournal of Experimental Marine Biology and Ecology, 227, 169-185.

Qiu, J.W. \& Qian, P.Y., 1997. Effects of food availability, larval source and culture method on larval development of Balanus amphitrite amphitrite Darwin: implications for experimental design. Fournal of Experimental Marine Biology and Ecology, 217, 47-61.

Raimondi, P.T., 1990. Patterns, mechanisms, consequences of variability in settlement and recruitment of an intertidal barnacle. Ecological Monographs, 60, 283-309.

Rainbow, P.S. \& Walker, G., 1977. The functional morphology and development of the alimentary tract of juvenile barnacles (Cirripedia: Thoracica). Marine Biology, 42, 337-349.

Rittschof, D., Branscomb, E.S. \& Costlow, J.D., 1984. Settlement and behaviour in relation to flow and surface in barnacle, Balanus amphitrite Darwin. Fournal of Experimental Marine Biology and Ecology, 82, 131-146.
Underwood, A.J., 1997. Experiments in ecology: their logical design and interpretation using analysis of variance. Cambridge: Cambridge University Press.

Walker, G., Yule, A.B. \& Nott, J.A., 1987. Structure and function in balanomorph larvae. In Barnacle biology (ed. A.J. Southward), pp. 307-328. Rotterdam: A.A. Balkema.

Wendt, D.E., 1996. Effect of larval swimming duration on success of metamorphosis and size of the ancestrular lophophore in Bugula neritina (Bryozoa). Biological Bulletin. Marine Biological Laboratory, Woods Hole, 191, 224-233.

West, T.L. \& Costlow, J.D., 1988. Determinants of the larval molting pattern of the crustacean Balanus eburneus Gould (Cirripedia: Thoracica). Fournal of Experimental Zoology, 248, 33-44. 